Bangladesh J. Zool. 42(1): 67-76, 2014

\title{
ABUNDANCE OF ZOOPLANKTON AND PHYSICO-CHEMICAL PARAMETERS OF A POLYCULTURE FISH POND OF MANIKGANJ, BANGLADESH
}

\author{
Pronob Kumar Mozumder* M. Niamul Naser and Abu Tweb Abu Ahmed \\ Department of Zoology, University of Dhaka, Dhaka-1000, Bangladesh
}

\begin{abstract}
Composition and abundance of zooplankton in a polyculture pond was studied during June 2003 to May 2004. A total of 33 major species of zooplankton including 11 genera of Rotifera, 4 of Copepoda, 4 genera of Cladocera and 2 genera of Protozoa were identified. The monthly abundance of zooplankton varied form 4228 indiv/1 in October 2003 to 169 indiv/1 in January 2004. Among the total zooplankton, Rotifera comprised of $71.07 \%$, Copepoda comprised of $12.49 \%$ Nauplii comprised of $11.96 \%$, Cladocera comprised of $1.49 \%$ and Protozoa comprised of $2.99 \%$. Water temperature $(\mathrm{r}=0.18)$, free $\mathrm{CO}_{2}(\mathrm{r}=0.40)$, TDS $(\mathrm{r}=$ $0.14)$ and water depth $(r=0.55)$ showed positive correlation with zooplankton but air temperature, $\mathrm{pH}$, dissolved $\mathrm{O}_{2}$, total hardness and ammonia showed negative correlation (the coefficients being $-0.18,-0.05,-0.25,-0.38$ and -0.11 respectively) with the occurrence of zooplankton. The average growth of fishes and zooplankton showed positive correlation in all cases but the relations were insignificant when tested statistically.
\end{abstract}

Key words: Zooplankton, physico-chemical factors, polyculture, abundance.

\section{INTRODUCTION}

The plankton, which lives in all the aquatic habitats, play a significant role in the overall biological productivity of natural waters, as they serve food to most of the fishes. Zooplankton are important food item of omnivorous and carnivorous fishes (Alam et al. 1987). Bardach et al. (1972) stated that the larvae of carps feed mainly on zooplankton. Zooplankton are the major mode of energy transfer between phytoplankton and fish (Howick and Wilhm, 1984). The study of zooplanktonic composition, abundance and seasonal variations is helpful in planning and successful fishery management (Jhingran 1974). So the production of fish is dependent on the zooplankton community, and they are one of the most important factors in fish culture due to their higher caloric content. So, abundance of zooplankton in polyculture pond is necessary for more fish production. The physico-chemical factors and nutrient status of water play the important role in governing the production of planktonic biomass. A number of workers such as Alam and Choudhury (2000); Ali et al. (1980, 1982, 1985); Ali and Begum (1979); Ali and Islam (1981); Mohsin et al. (1985); Banu et al. (1987); Hafizuddin and Nazimuddin. (1984); Bijoya and Latifa. (2005) have

*Author for correspondence. <pronob22du@yahoo.com>. This study was the part of the M. Phil. research of the first author (PKM). 
reported on different aspects of zooplankton inhabiting Bangladesh freshwaters. Sehgal (1967) and Michael (1966) worked in detail on physico-chemical factors and zooplankton population from different water bodies of India. However little information is available on the monthly variation of zooplankton and their relationship with the physico-chemical factors of water and fish growth in polyculture ponds of Bangladesh. Therefore, the present investigation is an attempt to examine the influence of physico-chemical factors on abundance, monthly diversity and composition of zooplankton and their relation on fish growth in a semi-intensive polyculture fish pond of Manikgonj, Bangladesh.

\section{MATERIAL AND METHODS}

The present study was carried out on fresh water pond at a private fish hatchery and nursery complex called "Jahan-E-Nizam Bahumukhi Krishi Khamar"in Manikgonj district from June 2003 to May 2004.The area is rectangular in shape, water surface area is 66 decimal (2672 cubic meter) and average depth of the pond varied from 2.75 to $3.65 \mathrm{~m}$. The pond bottom was muddy and no macro vegetation was evident. Water supply was dependent on rainfall and pumped water supply. During the study nursery pond was converted into rearing pond.

The monthly physico-chemical factors of the water were determined in the pond. The $\mathrm{pH}$ and dissolved oxygen (DO) were determined by digital $\mathrm{pH}$ meter (HANNA, China) and digital oxygen meter (HANNA, China) respectively. Free carbon dioxide $\left(\mathrm{CO}_{2}\right)$, hardness, ammonia, nitrite were determined by using $\mathrm{HACH}$ kit box (FF2, USA). A digital TDS (HANNA, China) was used to determine the transparency of water. At the time of sampling air and water temperature were recorded by a digital temperature meter (Fisher, U.S.A.).

The water samples for biological studies were taken from four different places of the pond from the surface and middle level of water in a plastic bucket on monthly basis. Water was collected with a 10 liter plastic bucket. First the water (30 liters) was sieved through plankton net $\left(64 \mathrm{mesh} / \mathrm{m}^{-2}\right)$. The concentrated plankton was adjusted to $18 \mathrm{ml}$ and preserved immediately in $4 \%$ buffered formalin solution.

For qualitative and quantitative study, zooplankton samples were examined under a compound microscope in a S-R (Sedgeweak-Rafter) cell using 100x magnification. The identification of zooplankton up to generic / species level were done with the help of Ward and Whipple(1959), Tonapi (1960), Mellanby (1975), Ali and Chakrabarty (1992) and Bhouyain and Asmat (1992). Quantitative analysis was followed by the total count method of Welch (1948). 
Statistical analysis: The relationships between zooplankton and physicochemical factors and average fish growth were established by correlations using Excel software of Microsoft office 2003.

\section{RESULTS AND DISCUSSION}

Zooplankton abundance: In the present study, five groups of zooplankton were recorded. Data obtained from the study indicates that a total of 33 zooplankton species were present in the pond comprising of 22 species of rotifers, 5 copepods, 4 cladocerans and 2 species of protozoans along with nauplius and metanauplius larvae. Highest number of zooplankton species (18) was observed in the month of August 2003 and lowest number of zooplankton species (7) was observed in the month of April 2004 (Table 1).

The rotifer was the most dominant group in the pond throughout the year. Kaliamurthy (1974) noted rotifers as the most dominant group followed by copepods, cladocerns, and ostracods. The dominance of Rotifera indicates the eutrophic nature of the water body. According to Brooks and Dodson (1965) selective predation by planktivorous fish results in the shifting of zooplankton communities with the dominance of rotifers (Table 2). Singh et al. (2002) reported that higher rotifer populations occurs during summer and winter due to hypertrophical conditions of the pond at high temperature and low level of water respectively. Monthly variation of zooplankton species in pond has shown in Table 1.

Monthly percentage distribution of zooplankton groups are showing in Table 2. Protozoa comprised $2.99 \%$ of the total zooplankton. The highest percentage of protozoan (13.64\%) was recorded in April 2004 and the lowest $(0.13 \%)$ in October 2003 (Table 2). Rotifera comprised $71.07 \%$ of the total zooplankton. The maximum percentage of rotifera (98.81\%) was recorded in October 2003 and the minimum (1.85\%) in June 2003 (Table 2). Copepoda and cladocera comprised $12.49 \%$ and $1.49 \%$ of the total zooplankton respectively. The highest percentage of copepoda (48.48\%) and cladocera (4.55\%) were recorded in April 2004. The lowest percentage of copepoda (0.02\%) was observed in August 2003 and that of cladocera (0.04\%) was recorded in October 2003 (Table 2). Nauplii comprised $11.96 \%$ of the total zooplankton. The highest percentage of nauplii $(45.37 \%)$ was recorded in June 2004 and the lowest (0.28\%) in July 2003 (Table 2).

The numerical variation in peak periods of different groups of zooplankton might be due to their biological parameters. During study, zooplankton density increased sharply through October'03 to December'03 (Fig. 1). This may be the result of less or inactive feeding of fish in winter months. Similar results were also observed by Ali et al. (1982). 


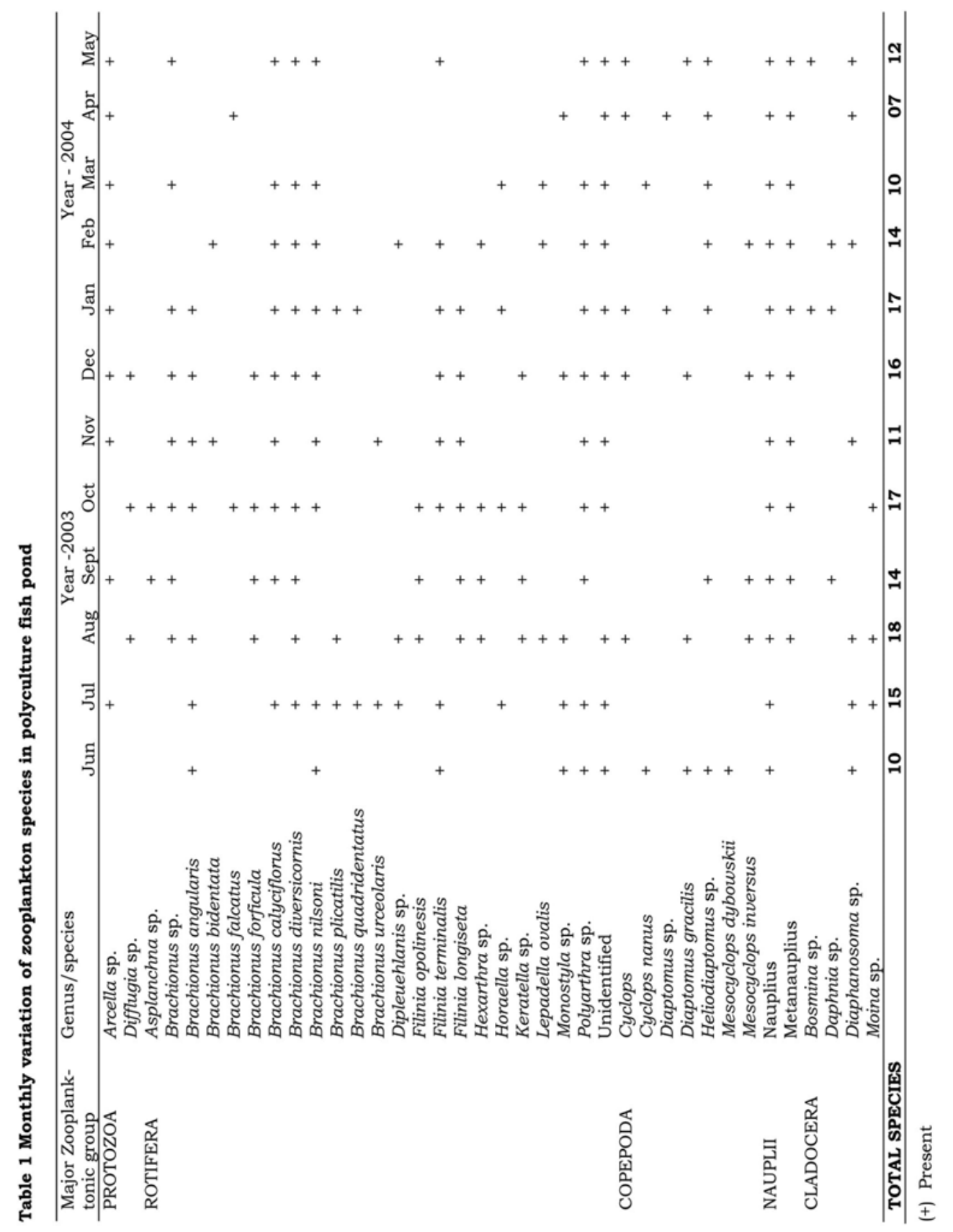




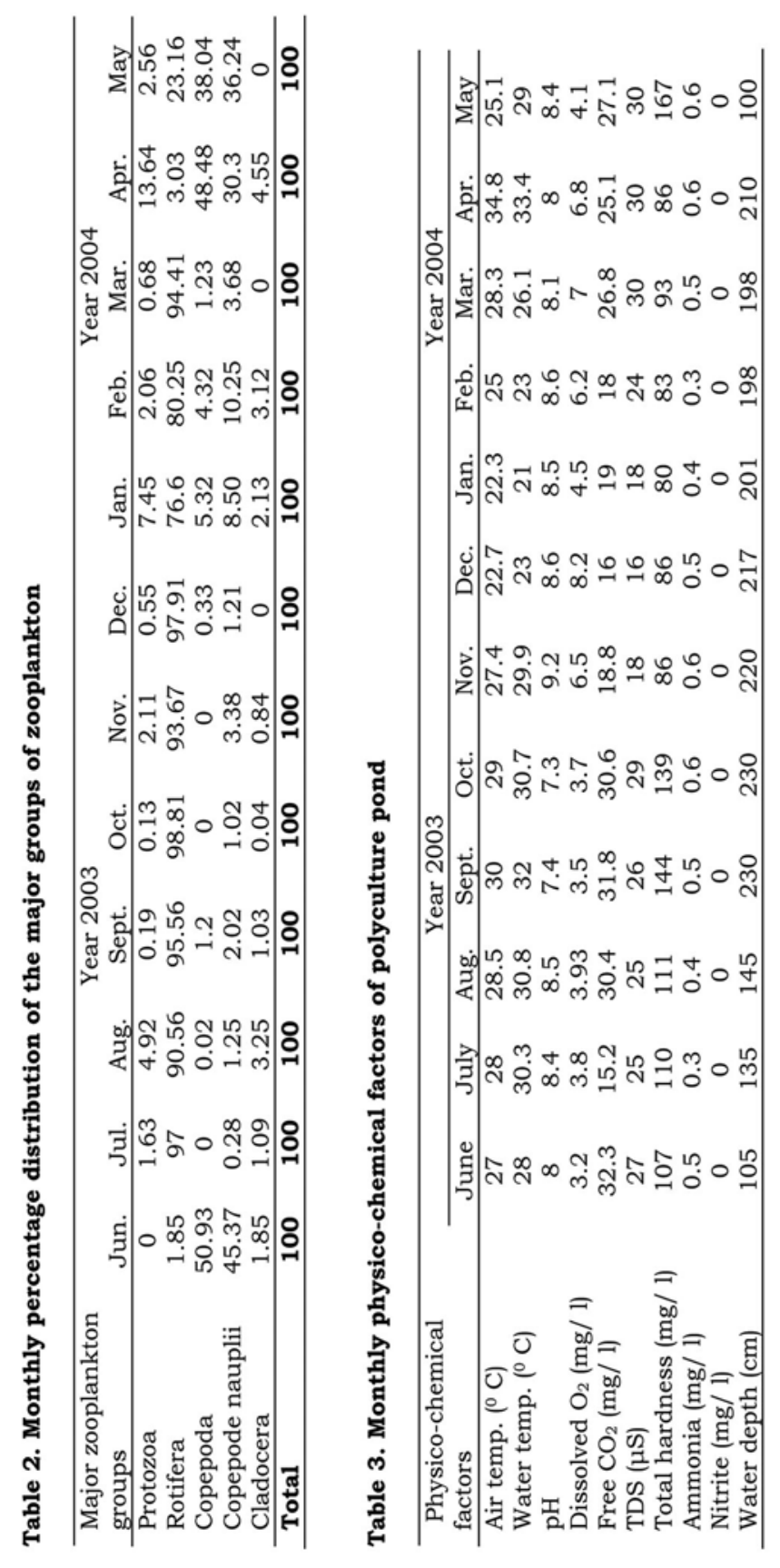


The monthly variation in zooplankton population (Fig. 1) showed that they varied from 169 indiv/1 to 4228 indiv/1 of pond water. The zooplankton showed its peak (4228 indiv/1) in October'2003, the minimum (169 indiv/1) zooplankton was observed on the January'2004 (Fig. 1). Das and Bhuiyan (1974) observed the greatest abundance of plankton in Dhaka city during the months of April May and October, and the greatest depletion was observed in the months of August and January - February.

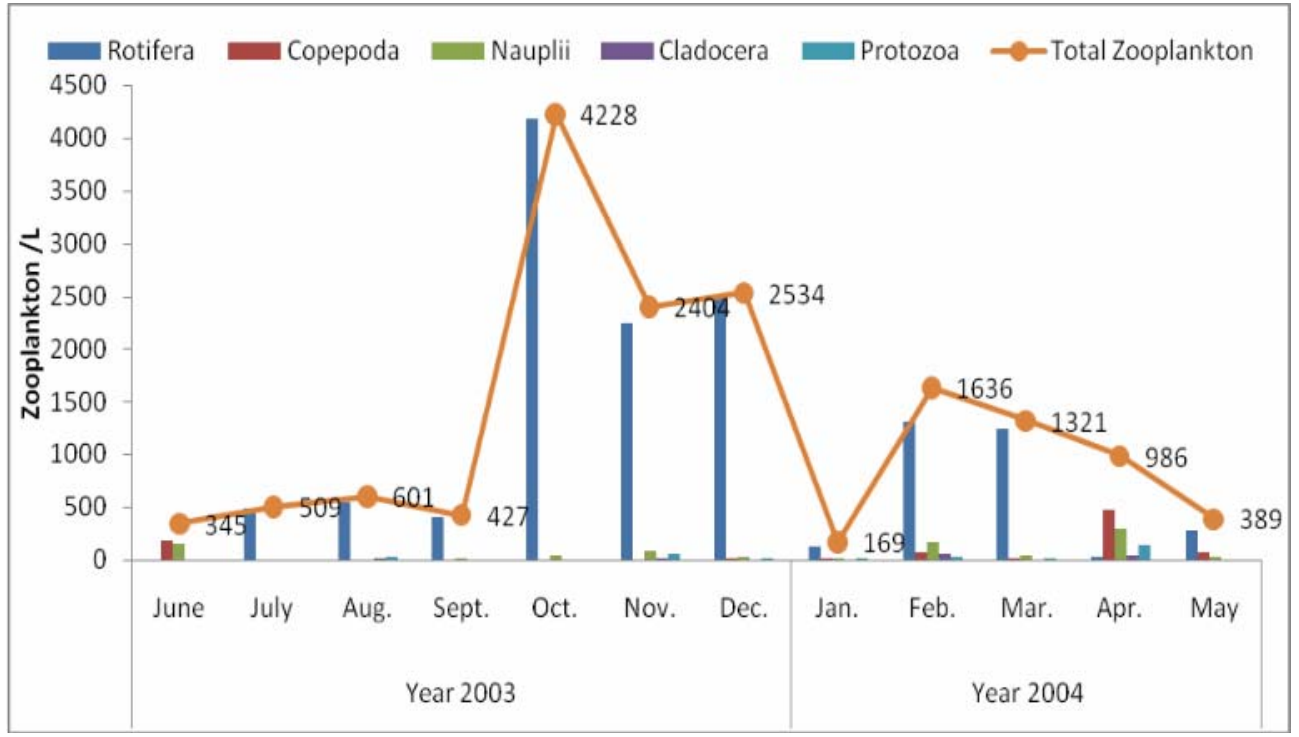

Fig. 1. Monthly variation of zooplankton population in pond

Physico-chemical factors: Monthly records of different physico-chemical factors showed fluctuations in different months, which are showing in Table 3.

The maximum water temperature $\left(33.4^{\circ} \mathrm{C}\right)$ and air temperature $\left(34.8^{\circ} \mathrm{C}\right)$ recorded in April'2004 (Table 3) and the minimum water temperature $\left(21^{\circ} \mathrm{C}\right)$ and air temperature $\left(22.3^{\circ} \mathrm{C}\right)$ recorded in January '2004. Similar result was observed by Miah et al. (1981) from Bangladesh pond. Similar trend had also been observed by Rao (1955). The water depth of the ponds was recorded. In polyculture pond it was found to be the lowest $198 \mathrm{~cm}$. in February 2004 and the highest $230 \mathrm{~cm}$. in September 2003 (Table 3) .The trend of increasing in depth towards the peak is related to the monsoon. Similar observation was observed by Michael (1969) from tropical water bodies.

During the study the lowest $\mathrm{pH}$ was in 7.3 (October 2003) and the highest was in 9.2 (November 2003) (Table 3). Such observation was supported by Michael (1969). The maximum concentration of dissolved $\mathrm{O}_{2}$ was $8.2 \mathrm{mg} / 1$ 
(December 2003) and the minimum $3.2 \mathrm{mg} / 1$ (June 2003) was recorded in pond (Table 3). Higher values of dissolve oxygen were observed at the surface water might be due to the wind action and also due to the active photosynthesis process. Similar trend had also been put forward by Ali et al. (1989). The maximum concentration of $\mathrm{CO}_{2}$ was $32.3 \mathrm{mg} / 1$ (June 2003) and the minimum $16 \mathrm{mg} / 1$ (December 2003) was recorded in pond (Table 3). Similar trend had also been put forward by Ali et al. (1989). The ammonia content in pond water was varied from $0.3 \mathrm{mg} / 1$ to $0.6 \mathrm{mg} / 1$ (Table 3 ). The value of total hardness varied from $80 \mathrm{mg} / 1$ to $144 \mathrm{mg} / 1$ during study period (Table 3). Ferdousi (1986) reported that low and high values of nitrite in the pond water might be associated with the phytoplankton populations, i.e. food availability in the pond. In the present experiment the nitrite was totally absent (Table 3). During study period the value of TDS varied from $16 \mu \mathrm{S}$ to $30 \mu \mathrm{S}$, which corresponds to the transparency (Table 3).

From the above observation it is found that, the physico-chemical conditions of the ponds were favourable for normal growth and life in the pond.

Coefficient of correlation among bio-physicochemical factors: Coefficient of correlation among bio-physicochemical factors are shown in Table 4 . In the present study the coefficient of correlation between water temperatures and occurrence of zooplankton showed positive $(0.18)$ correlation, whereas it showed negative (-0.18) correlation between air temperatures and occurrence of zooplankton. Ali et al. (1980) found that most of the zooplankton had positive correlation coefficient with temperature with the exception of the protozoans.

Table 4. Correlation co-efficient between physico-chemical parameters of water and density of total zooplankton of the polyculture pond.

\begin{tabular}{llc}
\hline Sl. & Relationship & Correlation co-efficient ' $r$ ' \\
\hline 1. & Air temp. Vs Total Zooplankton & -0.178 \\
2. & Water temp. Vs Total Zooplankton & 0.182 \\
3. & pH Vs Total Zooplankton & -0.051 \\
4. & Dissolved $\mathrm{O}_{2}$ Vs Total Zooplankton & -0.248 \\
5. & Free $\mathrm{CO}_{2}$ Vs Total Zooplankton & 0.399 \\
6. & TDS Vs Total Zooplankton & 0.139 \\
7. & Total hardness Vs Total Zooplankton & -0.380 \\
8. & Ammonia Vs Total Zooplankton & -0.113 \\
9. & Water depth Vs Total Zooplankton & 0.546 \\
\hline
\end{tabular}

During the study, zooplankton showed inverse relationship with $\mathrm{pH}$ (the coefficient being -0.05), which support the works of Patra and Azadi (1987) in Halda river of Bangladesh. The coefficient of correlation between $\mathrm{CO}_{2}$ and occurrence of zooplankton showed positive $(0.40)$ correlation. Total hardness 
$\left(\mathrm{HCO}_{3}\right)$ showed negative correlation, and TDS showed positive correlation with the occurrence of zooplankton (the coefficients being -0.38 and 0.14 respectively). The dissolved oxygen showed negative correlation with zooplankton (i.e. coefficient being -0.25) and Singh and Singh (1993) drew similar conclusion. The coefficient of correlation between water depth of pond and occurrence of zooplankton was found positive (0.55).

Table 5. Relationships between water temperatures, DO, and $\mathrm{pH}$, with average growth (by weight) of fishes in pond $(r=$ correlation; $t=t$ test value $)$.

\begin{tabular}{|c|c|c|c|c|c|c|c|c|c|c|}
\hline \multirow[t]{2}{*}{ Fishes } & \multicolumn{2}{|c|}{$\begin{array}{l}\text { Water temperature } \\
\text { and avg. growth }\end{array}$} & \multicolumn{2}{|c|}{$\begin{array}{l}\text { pH and avg. } \\
\text { growth of } \\
\text { fishes }\end{array}$} & \multicolumn{2}{|c|}{$\begin{array}{l}\mathrm{DO} \text { and avg. } \\
\text { growth of fishes }\end{array}$} & \multicolumn{2}{|c|}{$\begin{array}{l}\mathrm{CO}_{2} \text { and avg. } \\
\text { growth of fishes }\end{array}$} & \multicolumn{2}{|c|}{$\begin{array}{l}\text { Zooplankton and } \\
\text { avg. growth of } \\
\text { fishes }\end{array}$} \\
\hline & $\mathrm{r}$ & $\mathrm{t}$ & $\mathrm{r}$ & $\mathrm{t}$ & $\mathrm{r}$ & $\mathrm{t}$ & $\mathrm{r}$ & $\mathrm{t}$ & $\mathrm{r}$ & $\mathrm{t}$ \\
\hline $\begin{array}{l}\text { Catla } \\
\text { rohita } \\
\text { hybrid }\end{array}$ & -0.235 & -0.94 & -0.069 & -0.27 & 0.751 & 4.41 & -0.097 & -0.38 & 0.210 & 0.83 \\
\hline $\begin{array}{l}\text { Catla } \\
\text { catla }\end{array}$ & -0.178 & -0.70 & -0.104 & -0.40 & 0.708 & 3.91 & -0.072 & -0.28 & 0.235 & 0.94 \\
\hline $\begin{array}{l}\text { Labeo } \\
\text { rohita }\end{array}$ & -0.287 & -1.16 & -0.083 & -0.32 & 0.739 & 4.27 & -0.086 & -0.33 & 0.238 & 0.95 \\
\hline
\end{tabular}

Correlation between the average growth of fishes and bio-physico-chemical parameters: The correlation between the average growth of fishes and water temperature, $\mathrm{pH}$ and $\mathrm{CO}_{2}$ in pond although showed negatively correlation but the relations were insignificant when tested statistically. The correlation between DO and average growth of fishes showed positive correlation and the relationship was significant at $5 \%$ level of significance (Table 5). The average growth of fishes and zooplankton showed positive correlation in all cases but the relations were insignificant when tested statistically (Table 5).

The results revealed that the zooplankton abundance in fish culture pond varied from month to month. Among zooplankton groups, Rotifera appeared to be most dominating community throughout the study period.

Acknowledgements: The authors are deeply grateful to Dr. M. Shahadat Ali, Professor, Department of Zoology and former Pro-vice Chancellor, University of Dhaka, for his valuable suggestions during the research. The first author gratefully acknowledges the Ministry of Science, Information and Communication Technology (MSICT), Government of the People's Republic of Bangladesh for awarding the Research Fellowship. The authors are grateful to Kaji Tamanna Keya, Senior Research Officer, Population Council, Dhaka, for her assistance during the research. The authors are also grateful to Dr. Nurul Huda Tanvir, Director, Jahan-E-Nizam Bahumukhi Krishi Khamar for his support during the research. 


\section{LITERATURE CITED}

ALAM, A.K.M.N., ISLAM, M.A., MOLLAH, M.F.A. and HAQUE, M.S., 1987. States of zooplankton in newly constructed pond and their relation to some meteorolagical and limnologic factors. Bangladesh Journal of Fisheries, 10(1): 83-88.

ALAM, M.S. and CHOUDHURY, M.N. 2000. Species composition of copepods of Kaptai lake, Chittagong, Bangladesh. Proc. Conf. Zool. Soc. Bangladesh. Abs. No.33.

ALI, M. and ISLAM, M. A., 1981. Studies on the plankton of a lake in Bangladesh Agricultural University Campus. Bangladesh Journal of Fisheries, 10(1): 82-88.

ALI, S. and BEGUM, F. 1979. The chironomid larvae of Dhaka city. J. Asiat Soc.Bangladesh. 5(1): 89- 92.

ALI, S. and CHAKRABARTY, T. 1992. Bangladesher Mitha Panir Amerudandi Prani (A book of Freshwater Invertebrates of Bangladesh). $1^{\text {st }}$ edition. Bangla Academy, Dhaka, Bangladesh .pp.176.

ALI, S. RAHMAN, A. K. M. A., and PATWARY, A. R. P. 1982. Studies on the diurnal variation in physicochemical factors and zooplankton in a fish pond. Bangladesh J. Fish. 2(5): 15- 25.

ALI, S. SUKANTA, S. and MAHAMOOD, N.1985. Seasonal abundance of plankton in Moheskhali channel, Bay of Bengal. Proceedings of "SAARC Seminar on Protection of Environmental from Degradation”, Dhaka, Bangladesh, pp. 128-140.

ALI, S., CHOUDHURY, A. and ROY, A. R. 1980. Ecology and seasonal abundance of zooplankton in pond at Tongi, Bangladesh. Bangladesh J. Zool. 8(1): 11- 49.

ALI, S., CHOWDHURY, D. R., and BEGUM, S.1989. Studies on seasonal variations of physicochemical and biological conditions in a pond. Dhaka Univ. Stud.(Prt.-E) 4(2):113-123.

BANU, A. N. H., ALI, M. M. and ISLAM, A. 1987. Plankton study of some selected ponds in different locations of Bangladesh. Bangladesh J. Aquac. 9(2): 55-59.

BARDACH, E. J., RYTHER, H. J. and MELARNY, O.W. 1972. The farming and husbandry of fresh water and marine organisms, John-Willey and Sons, Inc. New York

BHOUYAIN, A. M. and ASMAT, S. M. 1992. Freshwater Zooplankton from Bangladesh. $1^{\text {st }}$ ed., pp. 137.

BIJOYA, G. and LATIFA, G. A. 2005. Seasonal distribution and abundance of zooplankton of Curzon Hall pond in relation to physic-chemical parameters .Proc.Conf. Zool.Soc.Bangladesh.Abst.No.34.

BROOKS, J. L and DODSONS, S. J. 1965. Predation, body size and composition of plankton. Sci. 150: 28-35.

DAS, N. G., and BHUIYAN, A. L. 1974. Limnoplankton of some inland waters of Dacca city. Bangladesh J. Zool. 2(1): 27- 42.

FERDOUSI, L. 1986. Limnological study of two ponds. Bangladesh J. Aquaculture. 55(1):12-16.

HAFIZUDDIN, A.K.M. and NAZIMUDDIN, M. 1994. Free - living planktonic copepods of Kaptai lake with a new record of genus Pseudodiaptomus and Orthocyclops from Bangladesh. Proc. Conf. Zool. Soc. Bangladesh. Abst. No.73.

HOWICK, G. L. and WILHM, J.1984. Zooplankton and benthic macroinvertebrates in Lake Carl Blackwell. Proceedings of Oklahoma Academy of Science. 64: 63-65.

JHINGRAN, V.G.1974. Fish and Fisheries of India .Hindustan Publishing Corporation, New Delhi.

KALIAMURTHY, M.1974.Observations on the plankto-ecology of Pulicate lake. Hydrobiol. 45: 86-95. 
MELlANBY, H. 1975. Animal Life in Freshwater. 6 ${ }^{\text {th }}$ ed. Trowbridge and Esher, Fedowood, Burn Ltd.pp.308.

MIAH, M. I., BHUIYAN, N. I. and DEWAN, S. 1981. A comparative study on the rate of growth of major carps in relation to physico-chemical and biological factors.Proc.3rd.Nat.Zool.Conf. Bangladesh, Dhaka.pp.215-224.

MICHAEL, G. R. 1969. Seasonal trends in physico - chemical factors and plankton of freshwater fish pond and their role in fish culture. Hydrobiol., 33(1):144-159.

MICHAEL, R. G. 1966. Diurnal variation in physico-chemical factors and zooplankton in the surface layers of three freshwater fish ponds. Indian. J. Fish. 12(1\&2): $48-82$.

MOHSIN, M., ISLAM, A. and HABIB, M. A. B. 1985. Monthly abundance of zooplankton in a pond. Univ. J. Zool. Rajshahi University.4: 42-49.

PATRA, R.W. R. and AZADI, M. A. 1987. Ecological studies on the planktonic organisms of the Halda river. Bangladesh J. Zool. 15(2): 109- 123.

RAO, C. B. 1955. On the distribution of algae in a group of a six small ponds. II. Algal periodicity. $J$. Ecol., 43: 291-308.

SEHGAL, K. L. 1967. Studies on Indian freshwater copepods. : On the calanoid copepods occurring in fish ponds .J. Zool. Soc. India.19(1\&2): 53:76.

SINGH, S. P. and SINGH, B. K. 1993. Observation on hydrobiological feature of river, Sonet at Diyapiper Bridge in Shahdo (M.P.). pp 135-138.

SINGH, S. P., PATHAK, D. and SINGH, R. 2002. Hydrobiological studies of two ponds of Santa (M.P.), India. Eco. Environ. Cons. 8: 289-292.

TONAPAI, G.T. 1960. Freshwater Animal in India (An Ecological Approach). Oxford and IBH Publishing Co., New Delhi. pp.341.

VLADIMIR, S. C. 1983. Rotifers as indicators of water quality. Hydrobiologia, 100(1):169-201.

WARD, H. B. and WHIPPLE, C. C.1959. Freshwater Biology. $2^{\text {nd }}$ ed. John Willy and Sons Inc., New York, London, pp.1248.

WELCH, P. S. 1948. Limnological Methods. McGraw- Hill Book Co.Inc.,New York. pp.381. 